\title{
Canola Yield Response to Levels and Application Methods of Nitrogen
}

\author{
Waqar $\mathrm{Ali}^{1 *}$, Saeed Anwar ${ }^{2}$, Muhammad Hashim Khan ${ }^{2}$, Jasim Iqbal ${ }^{1}$, Abid Kamal ${ }^{1}$, Zeeshan Ahmad ${ }^{3}$ \\ ${ }^{1}$ Department of Soil and Environmental Sciences, University of Agriculture, Peshawar, KPK-Pakistan; ${ }^{2}$ Department of Agronomy, University \\ of Agriculture, Peshawar, KPK-Pakistan; ${ }^{3}$ Department of Plant Breeding and Genetics, University of Agriculture, Peshawar, KPK-Pakistann
}

\begin{abstract}
Use of imbalance fertilizers and its application methods may cause reducing crops productivity. Therefore the proper level of fertilizers and appropriate methods is required to sustain the productivity of crops and soil fertility. Different levels of Nitrogen and its application methods were used to improve the canola productivity. A field experiment was conducted at University of Agriculture, Peshawar research farm in 2015-16. Randomized complete block design in split plot arrangement was applied with four replicates. Application methods (Broadcast method, rows one side placement, rows both side placement and rows between) were allotted to main plots and N levels (40, 70 and 90 $\left.\mathrm{kg} \mathrm{ha}^{-1}\right)$ were allotted to subplots. Experimental results exhibit that all the parameter were significantly $(\mathrm{p} \leq 0.05)$ different; maximum days to emergence (9), maximum number of plant $\mathrm{m}^{-2}$ (32), maximum days to first flowering (97), maximum grain pod $^{-1}(28)$, maximum 1000 grain weight $(3.2 \mathrm{~g})$, maximum grain yield $\left(985 \mathrm{~kg} \mathrm{ha}^{-1}\right)$ were noted at plot that fertilized with $70 \mathrm{~kg} \mathrm{ha}^{-1} \mathrm{~N}$ along with both side placement of rows. It can be concluded that $\mathrm{N}$ at $70 \mathrm{~kg}$ $\mathrm{ha}^{-1}$ and both side placement of rows produce a higher yield and yield attributes of canola.
\end{abstract}

Keywords: Canola; Fertilizers; Nitrogen; Yield; Crops productivity

\section{INTRODUCTION}

Canola (Brassica napus L.) is considered worldwide as the most vital protein and vegetable oil sources. Among the oil crops it ranked $3^{\text {rd }}$ and $5^{\text {th }}$ among important economically crops following wheat, maize rice and cotton [1]. The residues being left after extraction is a rich source of protein for livestock feed under cool temperature rapeseed grows best up to flowering. After flowering, the seed size, oil content and tolerant in high temperature [2]. Compare to other cereal crops the winter rapeseed required a high amount of nutrients. Nitrogen fertilizers play a vital role in improving the crop yield [3]. In the absence of essential nutrient the plant cannot complete the essential processes for all crops and $\mathrm{N}$ is an important factor. Proper nitrogen nutrition plays a positive role in plant survival. An excessive $\mathrm{N}$ rate or an inadequate moment of $\mathrm{N}$ application could increase $\mathrm{N}$ content in seeds, decreasing oil content and their commercial value [4]. Available nitrogen and proper sowing data are the most important factors affecting seed yield of oilseed rape [5]. Canola plant has a high demand for crop nutrients, including nitrogen and $\mathrm{N}$ deficiency commonly limit canola yield [6].

\section{MATERIALS AND METHODS}

A field experiment was led at University of Agriculture, Peshawar research farm during 2015-16 to assess the influence of different Nitrogen levels and its application methods on canola yield and yield parameters. The experiment was conceded out in randomized complete block design in split arrangement with four replicates. The subplot size was $3 \times 5 \mathrm{~m}$. The $\mathrm{N}$ levels $\left(40,70\right.$ and $\left.90 \mathrm{~kg} \mathrm{ha}^{-1}\right)$ were placed in subplot, while methods of application (broadcast method, rows one side placement, rows both side placement and rows between). All the cultural practices were uniformly kept throughout the experiments.

The factor and treatments details were given below.

Factor A (Nitrogen levels $\mathrm{kg} \mathrm{ha}^{-1}$ )

$\mathrm{T}_{1}=\mathrm{N} 40 \mathrm{~kg} \mathrm{ha}^{-1}$

$\mathrm{T}_{2}=\mathrm{N} 70 \mathrm{~kg} \mathrm{ha}^{-1}$

$\mathrm{T}_{3}=\mathrm{N} 90 \mathrm{~kg} \mathrm{ha}^{-1}$

Correspondence to: Waqar Ali, Department of Soil and Environmental Sciences, University of Agriculture, Peshawar, KPK-Pakistan, Tel: +92-3459557000; E-mail: waqarali@aup.edu.pk

Received: Arpil 26, 2019, Accepted: May 15, 2019, Published: May 22, 2019

Citation: Ali W, Anwar S, Khan MH, Iqbal J, Kamal A, et al. (2019) Canola Yield Response to Levels and Application Methods of Nitrogen. Agrotechnology 8:189. doi: $10.35248 / 2168-9881.19 .8 .189$

Copyright: (C) 2019 Ali W, et al. This is an open-access article distributed under the terms of the Creative Commons Attribution License, which permits unrestricted use, distribution, and reproduction in any medium, provided the original author and source are credited. 


\section{Factor B (Methods of application)}

1. Broadcast method.

2. Rows one side placement.

3. Rows both side placements.

4. Rows between.

The data recorded were days to emergence, number of plants $\mathrm{m}^{-2}$, days to first flowering, number of grain pod ${ }^{-1}, 1000$ grain weight (g), grain yield $\left(\mathrm{kg} \mathrm{ha}^{-1}\right)$ (Table 1$)$.

\section{Days to emergence}

Data was recorded by counting day numbers from sowings date to $80 \%$ emergence.

Number of plant $\mathrm{m}^{-2}$ : Data concerning plant $\mathrm{m}^{-2}$ was noted by plant number counting in one meter distance in each subplot randomly at three places then average was taken and converted by given formula.

Number of plant $\mathrm{m}^{-2}=\frac{\text { Number of Counted Plants }}{R-\text { R distance } \times \text { rowlength } \times \text { number of rows }}$

Days to first flowering: Data concerning days to first flowering counting the days from sowing date to plant show flowering.

Number of grains pod $^{-1}$ : Data about number of grain pod $^{-1}$ were counting the grains numbers per pod by randomly selected plants from each treatment then average were taken.

1000 grain weight (g): After threshing, 1000 grains were counted by counting machine and weighted.

Grain yield $\left(\mathrm{kg} \mathrm{ha}^{-1}\right)$ : Data concerning grain yield after threshing from each sub plot properly weighting and converted to $\mathrm{kg} \mathrm{ha}^{-1}$.

Grain Yield $=\frac{\text { Grain yield middle four rows }}{\text { No.of rows } \times \text { rowlength } \times R-R \text { distance }} \times 1000$

Statistical analysis: The recorded data were statically analyzed ( $\mathrm{p} \leq$ 0.05) through F-test [7].

\section{RESULTS}

Data regarding Table 2 days to emergence were not significantly

Table 1: Days to emergence, number of plant $\mathrm{m}^{-2}$, days to first flowering as affected by different nitrogen levels and its application methods in canola.

\begin{tabular}{|c|c|c|c|}
\hline Nitrogen Levels kg ha ${ }^{-1}$ & $\begin{array}{l}\text { Days to } \\
\text { Emergence }\end{array}$ & $\begin{array}{l}\text { Number of } \\
\text { Plant } \mathbf{m}^{-2}\end{array}$ & $\begin{array}{c}\text { Days to First } \\
\text { Flowering }\end{array}$ \\
\hline $\mathrm{T}_{1}=40$ & 8.5 & 28 & 85 \\
\hline $\mathrm{T}_{2}=70$ & 9 & 31 & 97 \\
\hline $\mathrm{T}_{3}=90$ & 9 & 29 & 93 \\
\hline $\mathrm{p} \leq 0.05$ & Ns & ** & $* * *$ \\
\hline \multicolumn{4}{|c|}{ Application Methods } \\
\hline Broadcast method & 10 & 29 & 92 \\
\hline $\begin{array}{c}\text { One side placement of } \\
\text { the rows }\end{array}$ & 9 & 29 & 97 \\
\hline $\begin{array}{c}\text { Two side placement of } \\
\text { the rows }\end{array}$ & 11 & 32 & 100 \\
\hline Between rows & 9 & 30 & 94 \\
\hline$p \leq 0.05$ & $* *$ & $* *$ & $* * *$ \\
\hline
\end{tabular}

Ns=Non-significant; $\mathrm{Ns}=\mathrm{p}>0.05 ;{ }^{* *} \mathrm{p} \leq 0.01 ;{ }^{* * *} \mathrm{p} \leq 0.001$
Table 2: Number of grains pod ${ }^{-1}, 1000$ grain weight $(\mathrm{g})$, grain yield $(\mathrm{kg}$ $\left.h^{-1}\right)$ as affected by different nitrogen levels and its application methods in canola.

\begin{tabular}{|c|c|c|}
\hline Physico-chemical Properties & Units & Values \\
\hline Texture & & Silt loam \\
\hline Bulk density & $\mathrm{g} \mathrm{cm}^{-3}$ & 1.28 \\
\hline $\mathrm{pH}(1: 5$ soil water extract $)$ & & 7.80 \\
\hline EC (1:5 soil water extract) & $\mathrm{dS} \mathrm{m}^{-1}$ & 0.16 \\
\hline Organic matter content & $\%$ & 0.85 \\
\hline Total Nitrogen & $\%$ & 0.34 \\
\hline AB-DTPA extractable phosphorus & $\mathrm{mg} \mathrm{kg}^{1}$ & 4.37 \\
\hline AB-DTPA extractable potassium & $\mathrm{mg} \mathrm{kg}^{1}$ & 85.23 \\
\hline
\end{tabular}

Table 3: Physico-chemical properties of soil of the experimental site.

\begin{tabular}{|l|c|c|}
\hline Physico-chemical Properties & Units & Values \\
\hline Texture & & Silt loam \\
\hline Bulk density & $\mathrm{g} \mathrm{cm}^{-3}$ & 1.28 \\
\hline $\mathrm{pH}(1: 5$ soil water extract $)$ & & 7.80 \\
\hline EC (1:5 soil water extract) & $\mathrm{dS} \mathrm{m}$ & 0.16 \\
\hline Organic matter content & $\%$ & 0.85 \\
\hline Total Nitrogen & $\%$ & 0.34 \\
\hline AB-DTPA extractable phosphorus & $\mathrm{mg} \mathrm{kg}^{-1}$ & 4.37 \\
\hline AB-DTPA extractable potassium & $\mathrm{mg} \mathrm{kg}^{-1}$ & 85.23 \\
\hline
\end{tabular}

affected by nitrogen level and application methods were significantly different from one another. In nitrogen level the maximum days to emergence (9) was observed when applied at $70 \mathrm{~kg} \mathrm{ha}^{-1}$ while minimum ( 8.5 days) was recorded from the plot fertilized with 40 $\mathrm{kg} \mathrm{ha}^{-1}$. In case of application method maximum days ware observed by both side of the rows, while the interaction was non-significant. In number of plant $\mathrm{m}^{-2}$, the maximum (30) were observed when nitrogen applied at $70 \mathrm{~kg} \mathrm{ha}^{-1}$, while minimum was observed at $40 \mathrm{~kg} \mathrm{ha}^{-1}$. In case of application methods, the maximum was observed in both sides placement of the rows. Data regarding days to first flowering, the maximum were observed from plot fertilized at $70 \mathrm{~kg} \mathrm{ha}^{-1}$, while minimum was observed from plot fertilized with $40 \mathrm{~kg} \mathrm{ha}^{-1}$. Similarly in application methods, the maximum days to flowering were observed in both sides of the rows, while minimum days related with broadcast, while the interaction was also non-significantly affected. In number of grain per pod, the maximum was recorded from plot which received $70 \mathrm{~kg} \mathrm{~N} \mathrm{ha-1}$, while minimum was at $40 \mathrm{~kg} \mathrm{ha}^{-1}$. In case of application methods, the maximum was recorded from both sides placement, while minimum was from one side placement. In 1000 grain weight, the maximum weight was observed from the plot fertilized with 70 $\mathrm{kg} \mathrm{ha}^{-1}$, while minimum was at $40 \mathrm{~kg} \mathrm{ha}^{-1}$. Similarly in application methods combination, the maximum was observed from both sides placement while minimum was from application method one side placement. Data regarding grain yield, the maximum $(985 \mathrm{~kg} / \mathrm{ha})$ was observed from the plot that had $70 \mathrm{~kg} \mathrm{~N} \mathrm{ha}^{-1}$, while minimum grain yield $(932 \mathrm{~kg} / \mathrm{ha})$ was related fertilized plot by $40 \mathrm{~kg} \mathrm{~N} \mathrm{ha}{ }^{-1}$. In case of application methods combination, the maximum grain yield was recorded from both sides placement, while minimum was recoded from one side placement.

The experimental site soil texture class was silt loam (Table 3). The $\mathrm{pH}$ was alkaline (7.80) and $\mathrm{EC}$ value (0.16) was less than $1 \mathrm{dS} \mathrm{m}^{-1}$ 
so the condition of the soil was non saline. The experimental site was medium in $\mathrm{P}$ content while $\mathrm{N}, \mathrm{K}$ and organic matter content was deficient.

\section{DISCUSSION}

Data regarding Table 2 showed days to emergence the nitrogen levels were non-significant and its application methods had effected significantly, while the interaction had affected non-significantly. The results are similar to [8] who indicated that days to emergence didn't response to nitrogen levels due to the physical properties of soil such as moisture etc. The number of per plant had significantly affected by both nitrogen levels and application methods, while the interaction affect was non-significant. The finding are correlated to [9] who stated the nitrogen enhance the vegetative and reproductive growth of canola. Days to first flowering response was significant in cases of nitrogen levels and application methods, while the effect was non-significantly in case of interaction. The results are in line with [10] who concluded that nitrogen fertilizers and broadcast method increased the photosynthesis rate, and the plant consumed more nitrogen as result more flowers in plant produced.

The number of grain per pod was affected significant in both nitrogen level and its application method, while interaction had non-significantly affected. The findings are in line with [11] who concluded that optimum nitrogen level and proper application method enhance the productive growth and more grain were produced. The 1000 grain weigh were also significantly affected by both factors, while the interaction affect was non-significant. The results are correlated with [12] who reported that proper nitrogen level increase the weight of grain due to high uptake of nitrogen which result heavier grain. Similarly, the grain yield affect were also significant in nitrogen level as well as the application method, while the interaction affect was non-significant. The results are in line with [13] who concluded that proper rates of nitrogen and its appropriate method had significantly increases the yield and its attributes.

\section{CONCLUSION}

Nitrogen level at70 $\mathrm{kg} \mathrm{ha}^{-1}$ and its application both sides placement had produced maximum days to emergence, days to first flowering, number of plants ${ }^{-2}$, grain per pod, 1000 grain weight, and grain yield. It is concluded from the given result that Nitrogen level at $70 \mathrm{~kg} \mathrm{ha}^{-1}$ and two side placement methods were recommended for higher yield and yield parameter of canola. Further studies are required to identify and integration of other organic with inorganic fertilizers on different crops under the different ecological zone of KPK.

\section{REFERENCES}

1. Khan N, Jan A, Ihsanullah, Khan IA, Khan N. Response of canola to nitrogen and sulphur nutrition. Asian J Plant Sci. 2002;1:516-518.

2. Ahmadi M, Bahrani MJ. Yield and yield components of rapeseed as influenced by water stress at different growth stages and nitrogen levels. AEJAES. 2009;5:755-761.

3. Hocking PJ, Randall PJ, Demarco D. The response of dryland canola to nitrogen fertilizer: Partitioning and mobilization of dry matter and nitrogen, and nitrogen effects on yield components. Field Crops Res. 1997;54:201-220.

4. Chamorro AM, Tamagno LN, Bezus R, Sarandón SJ. Nitrogen accumulation, partition, and nitrogen-use efficiency in canola under different nitrogen availabilities. Commun Soil Sci Plant Anal. 2002;33:493-504.

5. Almond JA, Dawkins TCK, Askew MF. Aspects of crop husbandry. Oilseed Rape. 1986;pp:350.

6. Grant CA, Bailey LD. Fertility management in canola production. Can J Plant Sci. 1993;73:651-670.

7. Jan MT, Hollington PA, Khan MJ, Sohail Q. Agriculture research: design and analysis. Deptt. of Agronomy, KP Agri Univ Peshawar, Pakistan. 2009.

8. Biswas DR, Ali SA, Khera MS. Response of gobhi sarson (Brassica napus L.) to nitrogen and sulphur. JISSS. 1995;43:220-223.

9. Jan A, Ahmad G, Arif M, Jan MT, Marwat KB. Quality parameters of canola as affected by nitrogen and sulfur fertilization. J Plant Nutr. 2010;33:381-390.

10. Kardgar V, Delkhosh B, Noormohammadi G, Shiranirad AH. Effect of nitrogen and plant density on yield of field mustard (Brassica compestris L.). Plant Physio. 2010;2:157-164.

11. Taylor AJ, Smith CJ, Wilson IB. Effect of irrigation and nitrogen fertilizer on yield, oil content, nitrogen accumulation and water use of canola (Brassica napus L.). Fertil Res. 1991;29:249-260.

12. Hamid, Shaheen MA. Response of seed yield, yield components and oil content of canola and nitrogen fertilizer rate diversity. Env Arid Land Agric Sci. 2007;20:21-31.

13. Rathke GW, Christen O, Diepenbrock W. Effects of nitrogen source and rate on productivity and quality of winter oilseed rape (Brassica napus L.) grown in different crop rotations. Field Crops Res. 2005;94:103-113. 